\title{
Gender Inequalities in the Workplace: Case Study of South Africa
}

\author{
Mavhuthu MUSETSHO \\ Nicoleta ISAC * \\ Cosmin DOBRIN ${ }^{3}$
}

\begin{abstract}
The South African government implemented different legislative mechanisms in an attempt to address gender equality in the workplace, discrimination, and empowering women. To review whether there has been any progress after implementing these legislative mechanisms, this paper empirically analyzes the advancement of gender equality in the South African workplace as of 2020. It also provides an overview of different legislative mechanisms implemented by the government of South Africa as an endeavor to achieve gender equality in the workplace and equal opportunities for all regardless of gender. The main objective of this paper is to review gender equality progress in the South African workplace and a qualitative research method has been used to analyze different gender inequalities. Lastly, the paper provides an overview of gender equality analysis in different occupational levels in the South African workplace. The research shows that regardless of the South African government's different legislative mechanisms to address gender equality, progress is still gloomy as discrimination against women in the workplace continues and the men remain dominant. The data analyses conclude that progress in addressing gender equality has been inert, delaying equal opportunities for all South Africans.
\end{abstract}

KEYWORDS: discrimination, gender equality, South Africa, women, workplace

JEL CLASSIFICATION: $J 16, J 71, J 83, K 38, M 54$

\section{INTRODUCTION}

It has been two decades and seven years since South Africa was declared a democratic country free from the apartheid regime, which collapsed in 1994. This year also marks twenty-six years since the Beijing Declaration and Platform for Action. Ever since the Platform for Action took place in 1995, South Africa has responded to a call to empower women and redress gender equality, mainly in the workplace. The Beijing Declaration and Platform for Action continue to be the driving force for addressing gender equality and empowering women (UN Women, 2020). For decades, women have been victims of discrimination, and this is not just a South African issue but a global issue that calls for all nations to work together (Sinden, 2017). Gender equality is a global issue that many democratic countries are yet to redress permanently. As a young democratic country, South Africa is still yet to redress all social, political, and economic issues initiated by the apartheid government. Until today, South Africa is still failing to overcome social, political, and economic issues such as gender equality, discrimination, high

\footnotetext{
${ }^{1}$ Istanbul Sabahattin Za1m University, Turkey, mmusechom@gmail.com

2* Istanbul Sabahattin Zaim University, Turkey, nicoleta.isac@izu.edu.tr, coressponding author

${ }^{3}$ Bucharest University of Economic Studies, Romania, cosmin.dobrin@man.ase.ro
} 
unemployment, poverty, fraud, corruption, and violent crime. Among all these issues, gender inequalities in the workplace seem to be the biggest issue against women's development and freedom from discrimination. Historically, the major obstacle to gender equality in the South African workplace has been caused by the apartheid regime system (Hills, 2015). However, most women remain worried as discrimination against them still exists in the workplace after twenty-six years of freedom. There is a need to accept that the apartheid regime system remains partly intact, which is one reason why progress and achievement of gender equality remain dally (Madala, 1999).

After the apartheid regime, many women in South Africa had better expectations and trust in the new government. This trust resulted from the new South African Constitution of 1996, which included the right to equality and the law's benefit. The new constitution was a great move to redress and liberate the previously disadvantaged group of people, particularly women. The constitution clearly emphasized equality as a right to everyone regardless of gender and race. During the apartheid government era, gender equality was not the only issue; discrimination was another problem that oppressed many women.

Due to the apartheid government system, South Africa had a horrible history of intolerable discrimination in the workplace, resulting in gender inequalities and significant gender disparities in the country (Standing, Sender \& Weeks, 1996). Notably, gender disparities and discrimination affected the virtual workplace's labor market (Rospabé, 2001; Parashar, 2014). According to the National Minimum Wage Panel (2016), the South African labor market is the core of gender inequalities and discrimination. Furthermore, it is also centralized by disparities in the distribution of income based on gender and race (Standing at el., 1996). Only a few workers earn a high income, and most are men (Fourie, 2011). The post-apartheid era has seen South Africa implementing commissions, policies, and legislation to redress gender equality and equal opportunity for all. Regardless of all these new policies and commissions to redress gender equality and discrimination in the workplace, change has slowly moved. The majority of women in the Republic of South Africa are still getting low income compared to men even though there are doing similar tasks in the workplace (Bhorat \& Goga, 2013). In South Africa, the post-apartheid era has mostly been characterized by addressing damages and errors caused by the apartheid government.

In terms of the South African Constitution of 1996, combat against gender inequalities and discrimination has been the government's objective to achieve (Sinden, 2017). Section 9 of the South African Constitution proves that the South African new government is committed to redressing gender equality in the country and workplace. This section (9) deals with the equality of everyone regardless of gender and race. It also addresses that no one should be maltreated or discriminated against because of their gender and race, and everyone has a right to equal opportunity. In the Post-1996, gender equality and justice have been the government's main optimistic agender to ensure impartiality in the workplace.

Although the process to eradicate gender inequalities seems gloomy and moving at a slow pace, South Africa performs better in the global endeavor to eliminate gender inequalities (Hills, 2015). It all started during the apartheid regime when women demonstrated against many inequalities such as poor working conditions, discrimination, child labor, and gender inequalities in the workplace (Bozzoli \& Nkotsoe, 1991). According to Naidoo and Kongolo (2004), the demonstrations of women against inequalities shaped the new South Africa; they contributed a lot as they campaigned for change and equal opportunities for all. However, the 
progress of gender equality remains unacceptably slow as discrimination against women persists (UN Women, 2020).

After all the demonstrations and campaigns by women against inequalities and discrimination, it became difficult for the government not to develop proactive policies and legislative mechanisms to address gender inequalities and discrimination in the workplace (Naidoo \& Kongolo, 2004). This move transpired the government to establish policies, commissions, and other legislative mechanisms to redress gender equality. South Africa's Bill of Rights is the main ground for addressing gender equality in the workplace and (Gouws, 1996) concludes that the South African 'Bill of Rights' introduction brought back women's dignity as equal citizens who have the right to similar opportunities as men. Following the Beijing Declaration and Platform for Action in 1995, the South African government reinforced the 'Bill of Rights' by promulgating other laws that deal with gender equality, employment, labor, and discrimination. The promulgated rules include, but not limited to, Labour Relations Act, No.66 of 1995, Commission on Gender Equity Act, 1996, Basic Conditions of Employment Act, 1997, Employment Equity Act, No. 55 of 1998, Women Empowerment and Gender Equality Bill, and Promotion of Equality and Prevention of Unfair Discrimination Act, 2000. All these legislative mechanisms will be explained further in this paper. According to Naidoo and Kongolo (2004), the main objective of putting new laws in force is to ensure gender equality and equal opportunities for all.

\section{LITERATURE REVIEW}

Globally, gender inequalities study has been conducted for many years (Wu \& Cheng, 2018). One of the earlier studies on gender inequalities by Seidman (1993) reveals that South African nationalist agender to improve women status has been a promise for a century. Unfortunately, these promises have materialized to nothing as women remain bound and oppressed in the workplace (Seidman, 1993). Also, the author observes that the lack of participation of women in the workplace has been there since the 1980s. He further suggests that the new South African government should address gender inequalities, particularly in labor. Historically, most women have been denied participating in many places and activities such as wealth creation, laws, economic activities, high positions in the workplace, and science (KellyGadol, 1976). Kelly-Gadol (1976) emphasized the need to restore all women to their rights. The issue of gender inequalities is not new as it can be traced back to the $20^{\text {th }}$ century.

Since then, many studies on gender inequalities have been conducted. A recent survey by Begeny et al. (2020) indicated that women are becoming more present in the workplace, yet gender partiality persists. The authors contend that most women who work inside men's dominant professions are more likely to experience discrimination. However, transformation is taking place in many of men's dominant disciplines to have more women presented (Huang, 2017). Begeny et al. (2020) posit that the current studies indicated that progress on gender inequalities should not be contemplated as a robust solution to gender equality. The research shows that there is more that is still to be done in addressing gender imbalances in the workplace.

Another recent study in South Africa indicates that the number of women in high and managerial positions in the workplace continues to be less (Espi et al., 2019). Espi et al. (2019) evaluate the reliability of the Employment Equity Act, No. 55 of 1998 in addressing gender imbalances; using the employment data, they observe that women continue to be well represented only in lower positions. Sinden (2017) discovers that, regardless of aggressive 
policies and laws implemented to address gender inequalities, women remain less represented in the workplace. The author points out that the transformation in redressing gender equality and discrimination in the workplace remains gloomy. Furthermore, Sinden's (2017) findings reveal that men are dominant and continue to occupy high positions in the workplace. Meaning that there is still a need to redress gender equality in the workplace as women continue to be oppressed and discriminated against.

Globally, addressing gender equality or equal treatment of every employee has received exceptional attention in the workplace (Wu \& Cheng, 2018). Through their study, Wu and Cheng (2018) posit that gender equality is crucial in the workplace because it provides productivity and growth. However, it seems as if we have to wait for some time to see exceptional progress in attaining gender equality in the workplace. While gender inequalities persist in the workplace, women remain the victim, bound, and oppressed. Freedom from gender inequalities and discrimination cannot be attained unless women can be emancipated from all manner of oppression (Hills, 2015).

Recent findings in South Africa show that most men and women agree that there has been good progress in achieving gender equality in the workplace. Furthermore, Naidoo and Kongolo (2004) contend that statistics from different research papers indicate that there has been some change in redressing gender equality; women are now represented in high and managerial positions in the workplace. Another recent research article confirms that there has been some positive movement in recruiting more women into high occupational levels in the workplace. Nevertheless, there is still more to be achieved on this issue (O'Brien, 2019). Frankiewicz (2020) studied gender imbalances in the workplace and observed that men and women might have similar opportunities to get into the workplace. Yet, most women tend to fall behind in terms of getting promotions and managerial positions. Globally, companies fail to find a clear plan on how they can merge the gap between men and women in the workplace (Frankiewicz, 2020).

In research data presented by Ortiz-Ospina and Roser (2018), gender inequalities in many countries have decreased notably on the gender pay gap between men and women in the workplace. The research data further demonstrated that women are still underrepresented worldwide in the workplace (Ortiz-Ospina \& Roser, 2018). Gender inequalities are not an issue that can be addressed overnight; there is a need to be patient (Khuzwayo, 2016).

\section{LEGISLATIVE MECHANISMS - REDRESSING GENDER INEQUALITIES IN THE WORKPLACE}

This section focuses on legislative mechanisms and statutory directives implemented by the South African government to combat gender inequalities, injustices, and unfair discrimination in the workplace. South African overall inequalities and discrimination have been addressed in the supreme legislation, namely the Constitution Act 108 of 1996, whose main objective is to build a better country where everyone, regardless of gender, is equal (Sinden, 2017). Section 9 of the South African Constitution proves that the new South African government mandates gender inequalities in the workplace. In section 9 (3) of the South African Constitution, everyone, regardless of gender and race, is equal before the law. No one should be maltreated or discriminated against because of their gender and race, and everyone has a right to equal opportunity. According to Geisler (2009), South African Constitution is one of the world's proactive constitutions, which value human dignity, equality for all, and progress and development of human rights and freedom. Similarly, Bentley (2004) and Sinden (2017) 
emphasized that the South African Constitution adopted strategies toward building a democratic society where men and women can have equal opportunities. However, the challenge remains to harness positive results from the implementation of the constitution as women continues to suffer discrimination (Kehler, 2001).

The Employment Equity Act, No. 55 of 1998 recognizes that as a result of the apartheid regime policies, there are imbalances and gender disparities in the workplace. These gender disparities created disadvantages for certain groups of people, especially women. They cannot be amended simply by canceling discriminatory laws; therefore, promoting equality and eliminating unfair discrimination in the workplace is necessary. According to Espi et al. (2019), Employment Equity Act was introduced after the apartheid era injustices to address pervasive inequalities in the South African workplace. The primary mandate of the Employment Equity Act is to achieve gender equity in the workplace by ensuring fair treatment, equal opportunities, eliminating unfair discrimination, and implementing affirmative action measures to ensure equality for all (South African Department of Labour, 1994). Sinden (2017) note that organizations are expected to participate in employment equity measures and take the responsibility to create an equal workplace environment for everyone, especially the previously disadvantaged groups like women.

The Commission on Gender Equity Act, no 39 of 1996 is a statutory body notified and assented by the South African government to promote gender equality and give advice and make recommendations to the parliament on matters that affect gender equality and the status of women. The commission is obligated to submit an annual employment equity report to the minister of Employment and Labour in terms of section 33 of the Employment Equity Act. In addition, the commission is responsible for developing, facilitate and supervise educational programs to educate the public about gender equality matters (Sinden, 2017). Furthermore, Meintjes (2005) point out that the Commission on Gender Equality can resolve any constitutional issues that have to do with gender inequalities, which gives the commission power to dispute and conduct constitutional court matters.

In an attempt to promote gender equality intensively, the South African government established the Promotion of Equality and Prevention of Unfair Discrimination Act. This Act effectively deals with the prevention and prohibition of unfair discrimination and harassment in the workplace to protect human rights and promote gender equality. Additionally, it stipulates that the Act endeavors to facilitate the transition to a democratic society, unity in diversity, freedom, human dignity, and gender equality. Kok (2008) recognizes the Promotion of Equality and Prevention of Unfair Discrimination Act as one of the most relevant legislative mechanisms to undo the apartheid regime's oppression and injustices. It outlaws gender inequalities and unfair discrimination in various spheres of society and prevents and prohibits harassment (Kok, 2008).

Another legislative mechanism to combat gender inequality is the Women Empowerment and Gender Equity Bill. The South African government established this legislative framework to effect section 9 of the country's Constitution, which deals with gender equality. Based on concerns raised about the lack of the empowerment of women and gender equality, the government established this framework to align all aspects of laws and implement laws focusing on empowering women by ensuring the representation of women in high decisionmaking positions and structures. This means that women should be appointed in high positions like management, leadership, and governor. It took twenty-five years since 1994 for 
the new South African government to select half of the cabinet's ministers as women for the first time in its history.

Apart from the Women Empowerment and Gender Equity Bill, the South African government established the policy framework titled 'South Africa's National Policy Framework for Women's Empowerment and Gender Equality. The Presidency proposed the framework to strategize the vision of gender equality and how unfair discrimination can be eliminated. It deals with guidelines for South Africa as a nation to rectify the injustices created by the apartheid regime policies by implementing new effective treaties and frameworks to promote equality for both men and women (Kornergay, 1999). Kornergay (1999) added that the Gender Policy Framework is responsible for ensuring that practical steps to achieve gender equality are monitored and become the center of all structures, institutions, and government programs within South Africa.

As discussed above, it can be seen that the democratic government of South Africa has implemented vast statutory measures to promote gender equality and eliminate unfair discrimination in the workplace. However, it is imperative to monitor these frameworks' progress and effectiveness as to whether they are achieving desired results in the workplace. Having multiple legislative frameworks will not change the status of women in the workplace; it is the effectiveness of the implementation of these frameworks that will bring change thereof (Sinden, 2017).

\section{METHODOLOGY}

The research paper used qualitative methods to gather information. The primary data used in this paper was sourced from the South African Department of Labour's 20th Commission for Employment Equity Annual Report 2019/2020. The trend analysis is based on the recent period for three years, from 2017 to 2019. The data contain 27,127 reports received from different sectors, and a total of 7,332,072 employees from local government 195,474; provincial government 503,421; national government 369,280; private sector 5,294,165; nonprofit organizations 468,247; state-owned companies 123,574; and educational institution 377,911 . Secondary data were acquired from various sources such as books, journals, and government departments.

\section{DATA ANALYSIS}

As discussed above, the Republic of South Africa has implemented various policies, statutes, regulations, and legislation to redress imbalances created by the apartheid policies. Redressing the injustices created by the apartheid regime requires proactive policy measures and statutory involvement. According to the Department of Labour (2019), in its $20^{\text {th }}$ Commission for Employment Equity Annual Report, men remain dominant in high occupational levels, while women remain underrepresented. This section will give us decent feedback on whether there is any exceptional advancement in redressing unfair discrimination and gender inequalities in the workplace. 


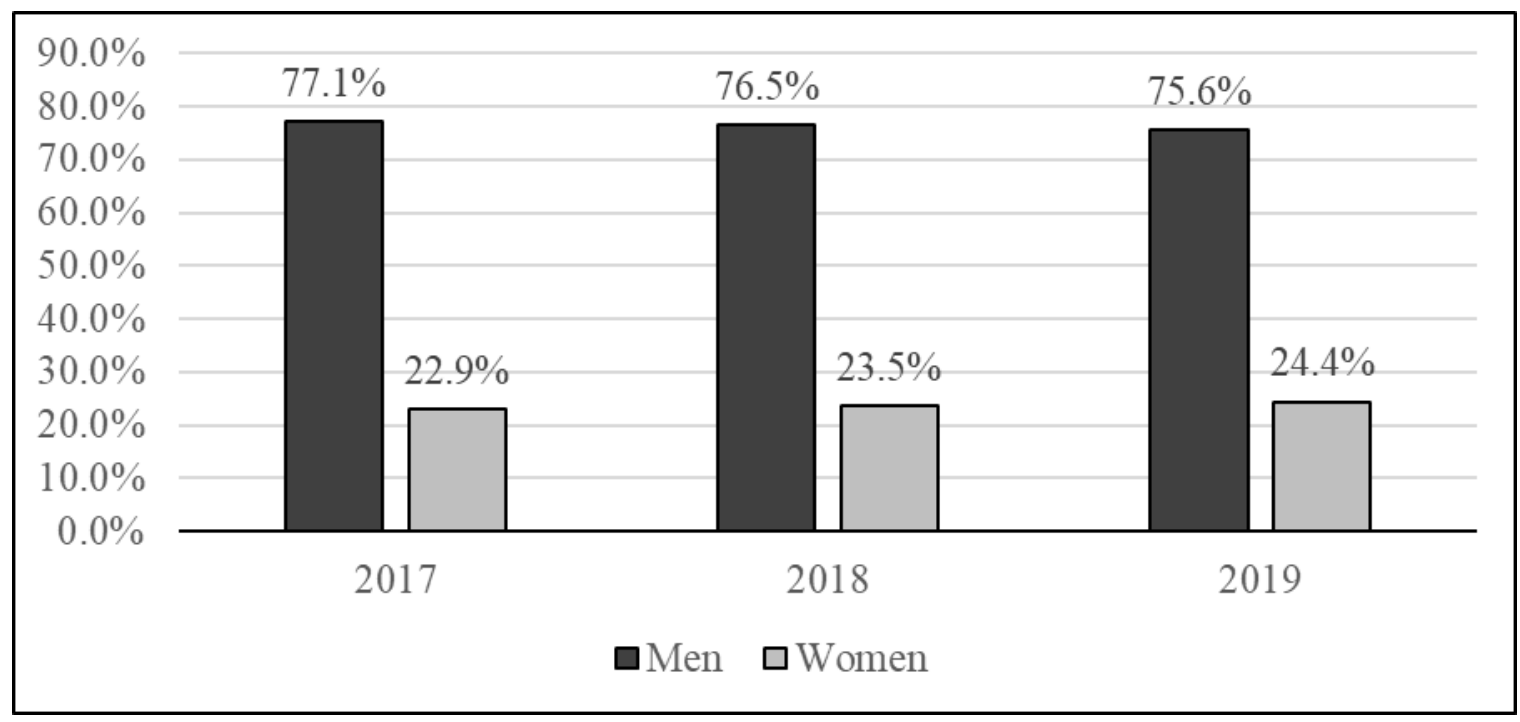

Figure 1. Workforce Profile by Gender - Top Management

Source: Adapted from Department of Labour (2019, p. 16)

Figure 1 shows trend analysis in top management occupational level by gender from 2017 to 2019 and the men have dominated the top management occupational level by a far higher percentage than women. We can observe there is a slight increase of $0,6 \%$ from 2017 to 2018 and $0,9 \%$ from 2018 to 2019 . This is a fall behind and a delay to the vision and the mandate of the South African government to empower women and promote gender equality in the workplace. Women remain under-represented in top management occupational level, which raises concerns on gender inequalities issues in the workplace. The annual increase of women is less than $1 \%$ at this occupational level. The change is happening at a low pace resulting in a lot of impatience from most women.

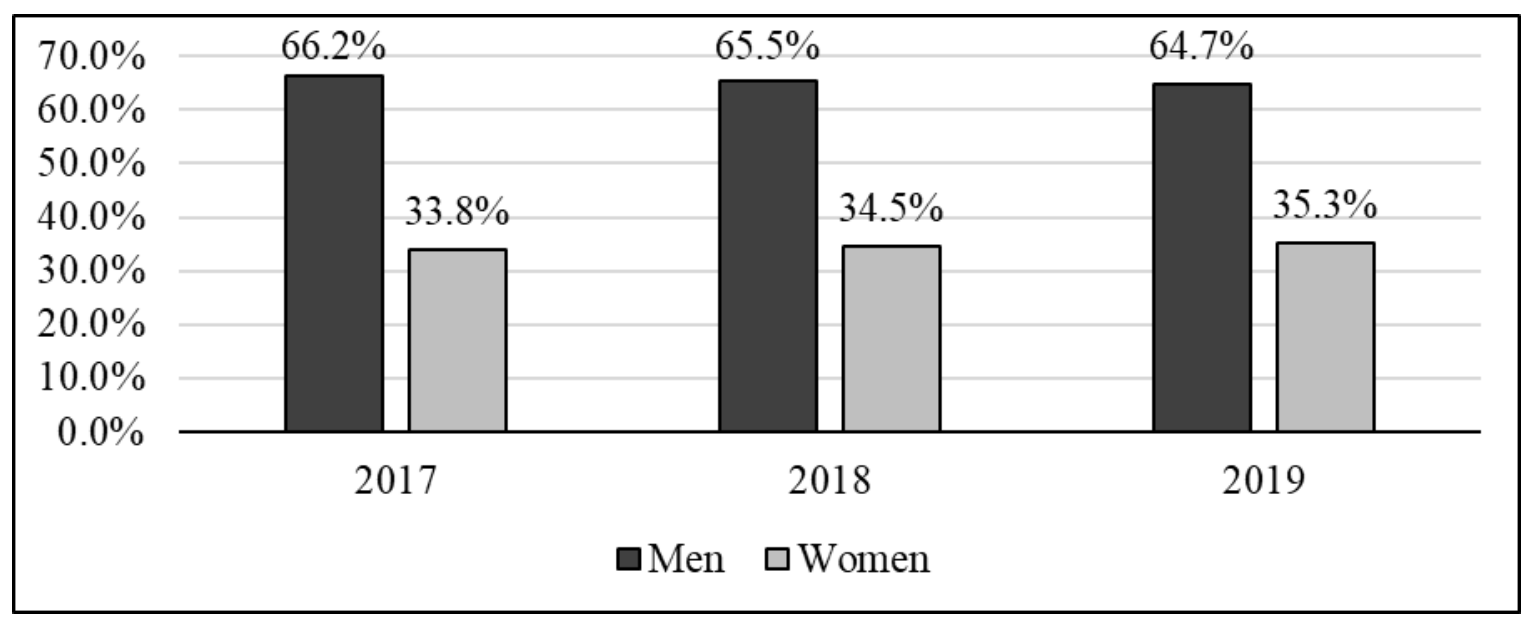

Figure 2. Workforce Profile by Gender - Senior Management

Source: Adapted from Department of Labour (2019, p. 19)

Figure 2 shows that women are still underrepresented at the senior management occupational level even though the situation is slightly better than at the top management occupational level. Gender equality is still far from being achieved as women occupy less than $50 \%$ of the senior management positions. Like in top management, the annual increase of women remains at less than $1 \%$ average in a year. This is not a good report toward redressing the imbalances in the workplace. Men remain dominant as they occupied more than $50 \%$ of senior management positions. The gap between men and women is $30 \%$ in 2019 . This is a vast 
opening to merge as the annual average increase of women in senior management occupational level remains at less than $1 \%$. It will take many years of patience to eliminate gender inequalities in the workplace.

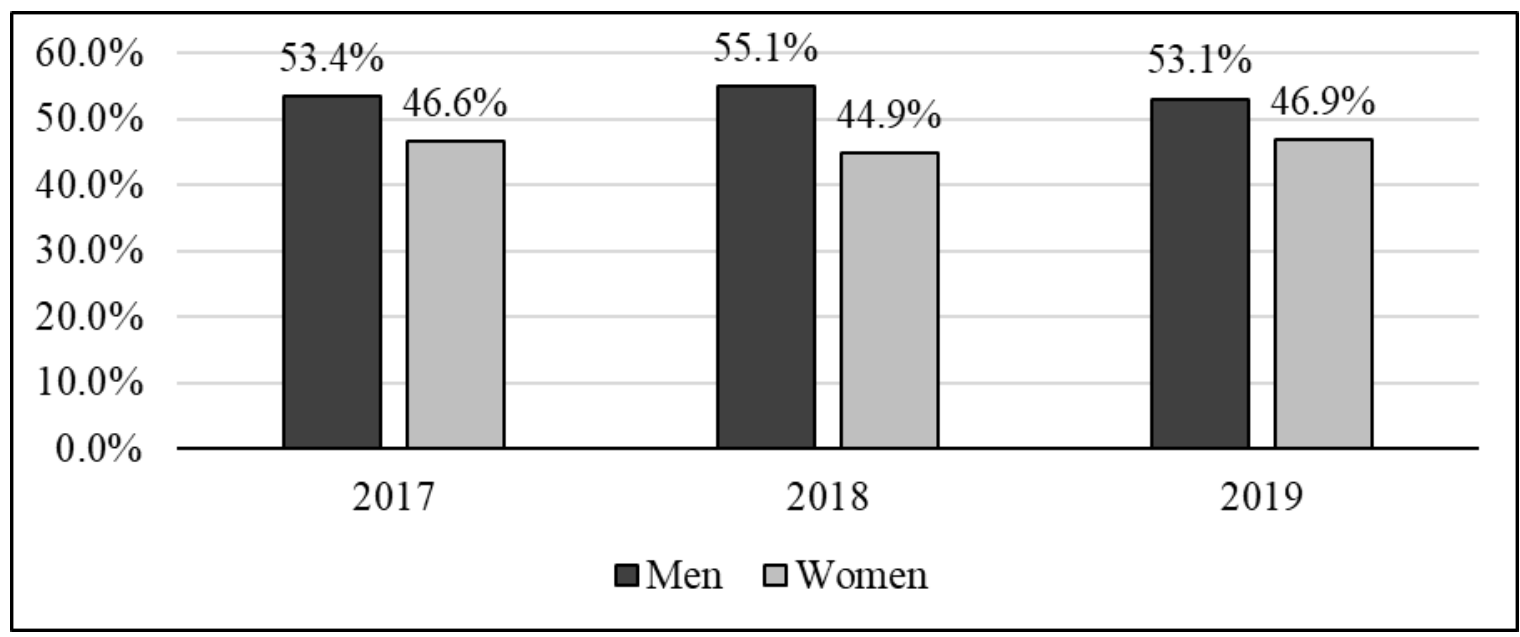

Figure 3. Workforce Profile by Gender - Professionally Qualified

Source: Adapted from Department of Labour (2019, p. 23)

Figure 3 shows that professionally qualified occupational level has remained predominantly male dominant. However, it is interesting to see an encouraging trend; female representation accounts for $46,9 \%$ in 2019 , slightly below male's $53,1 \%$. The gap between men and women is only $6,2 \%$ in 2019, which is not a huge gap compared to the senior management occupational level. This is positive feedback toward redressing historical injustices, discrimination, and gender inequalities in the workplace. However, there are still more duties to be done in terms of empowering women in the workplace. As most women become professionally qualified, we can hope for things to become better in the workplace.

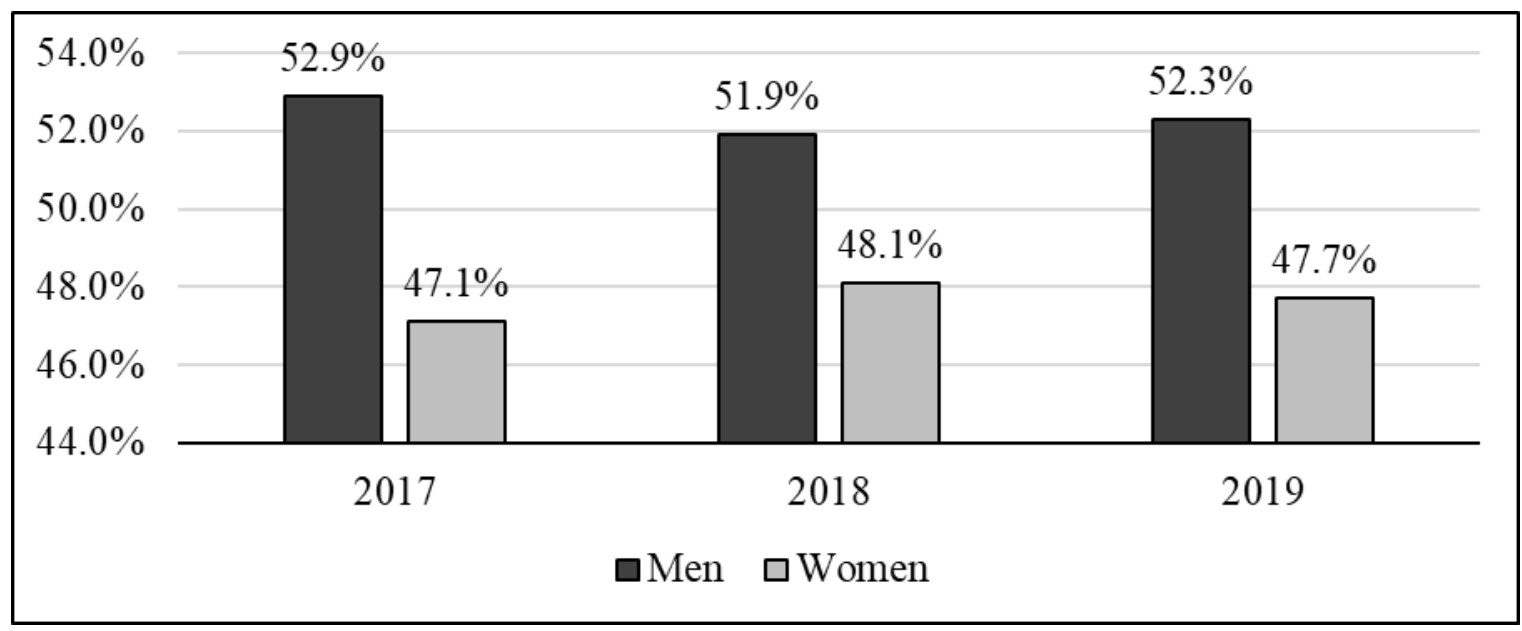

Figure 4. Workforce Profile by Gender - Skilled level

Source: Adapted from Department of Labour (2019, p. 26)

Figure 4 shows that women continue to be underrepresented at the skilled occupational level as they occupy less than $50 \%$ of the positions in the workplace. From 2017 to 2018, there is a $1 \%$ annual increase for women in this occupational level. However, a decrease of $0.4 \%$ from 2018 to 2019 is a step backward toward redressing gender inequalities in the workplace. Men continue to occupy more than $50 \%$ of the positions in the skilled occupational level. The figure also shows that there was an increase in men in 2019. This is contradicting the 
government's plan to recruit more women in the workplace. It is a negative impact on gender transformation.

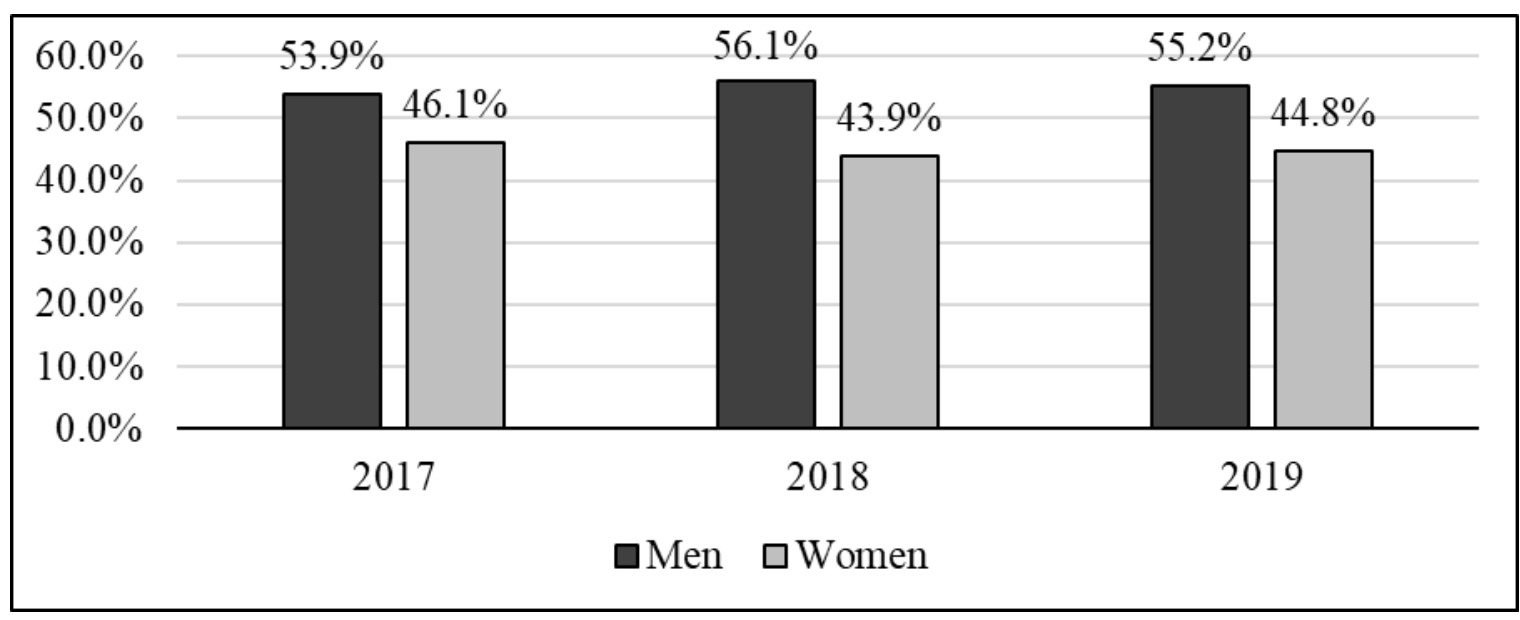

Figure 5. Workforce Profile by Gender - Semi-skilled level

Source: Adapted from Department of Labour (2019, p. 30)

Figure 5 shows trend analysis in semi-skilled occupational level by gender from 2017 to 2019. It shows that men have been dominating in this occupational level in comparison with women. In 2019 men occupied positions 10\% more than women, which is a vast percentage gap. There is just a tiny increase of $0,9 \%$ for women from 2018 to 2019. The increase cannot be regarded as enough as women continue to be underrepresented in the workplace.

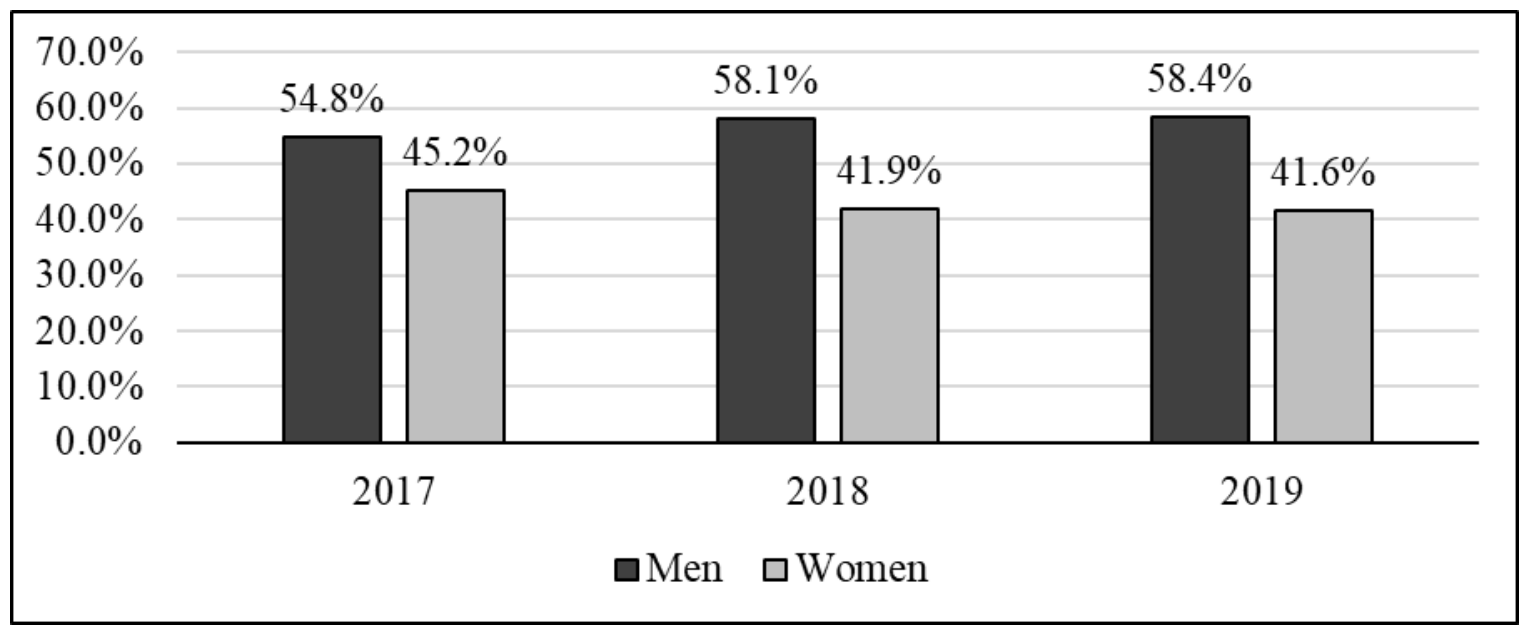

\section{Figure 6. Workforce Profile by Gender - Unskilled level}

Source: Adapted from Department of Labour (2019, p. 33)

Figure 6 shows that unskilled occupational level has remained predominantly men dominant. Yet, women remain underrepresented at this occupational level. Since 2017, the trend analysis shows that the percentage of women has been decreasing. This is not what the majority of women want to see. Women are still underrepresented in all occupational levels, which is not good in redressing gender inequalities in the workplace. For quite a while, men have been dominating in the workplace at all high occupational levels. The journey to eliminate gender inequalities in the workplace is still a long one; there is a lot that the government needs to work out to achieve gender equality in the workplace. 


\section{CONCLUSIONS}

The South African problem of gender inequalities and unfair discrimination in the workplace originated from far back in the apartheid government era. After the collapse of the apartheid regime era in 1994, the new government introduced 'Equality' as a right in the 1996 South African Constitution, the supreme law. It was then that 'Equality,' regardless of gender, race, and culture, was adopted as a human right. This was a reinforcement commitment by the government to redress gender parities created by the apartheid regime injustices. The Constitution is viewed as the core and center of human rights, promoting equality to all South Africans. There are other critical legislative frameworks such as the National Policy Framework for Women's Empowerment and Gender Equality, Women Empowerment and Gender Equity Bill, and the Promotion of Equality and Prevention of Unfair Discrimination Act. All these legislative frameworks originate from the South African Constitution, which is the supreme law.

From the viewpoint of this study, the government of South Africa is well aware of the problems related to gender inequalities and unfair discrimination in the workplace. Despite implementing various legislative programs, policies, and statutory measures to eliminate gender inequalities and unfair discrimination in the workplace, most women in South Africa are still facing unfair discrimination. The representation of women in high positions such as management and leadership is shallow. In all the top four occupational levels (top management, senior management, professionally qualified, professional level), women are still underrepresented, and men remain dominant. There is a need for a full review of all legislation regarding gender equality and unfair discrimination.

It is unfortunate that the government will always try to hide behind the apartheid regime injustices as the cause of gender inequalities and discrimination in the workplace. Although the apartheid government unfairness cannot be avoided, it can neither be an excuse for the lack of representation of women in high positions in the workplace. It is now almost three decades since the apartheid government collapsed in 1994. This alone shows that the government still has more to do to address gender equality in the workplace. Apart from using legislative frameworks as the main tools to combat inequalities, there is a need to take responsibility and action rather than establishing policies after policies.

To eliminate gender inequalities in the workplace, the government should introduce proactive and aggressive strategies to enforce and speed up progress. Otherwise, equality in the workplace will remain nothing but a 'mere wish' for South African women. Although it cannot be denied that there have been some changes in recruiting women to occupy high positions in the workplace, the process is prolonged and ineffective. To address gender inequalities and unfair discrimination in the workplace, the focus should be on enforcing real change and speedy progress. The goal should not be 'talking about change,' but the talk should become a reality.

\section{REFERENCES}

Amendments, S.C. (2013). Republic of South Africa Select Committee Amendments To Women Empowerment and Gender Equality Bill. 37005, 7-9.

Begeny, C.T., Ryan, M.K., Moss-Racusin, C.A., \& Ravetz, G. (2020). In some professions, women have become well represented, yet gender bias persists - Perpetuated by those who think it is not happening. Science Advances, 6(26). https://doi.org/ 10.1126/sciadv.aba7814 
Bentley, K. (2004). Women's human rights and the feminisation of poverty in South Africa. Review of African Political Economy, 31(100), 247-261. https://doi.org/10.1080/ 0305624042000262275

Bhorat, H., \& Goga, S. (2013). The gender wage gap in post-apartheid South Africa: A re-examination. Journal of African Economies, 22(5), 827-848. https://doi.org/10.1093/ jae/ejt008

Bozzoli, B. \& Nkotsoe. M. (1991). Women of Phokeng. Johannesburg: Raven.

Dryding, D. (2019). Despite progressive laws, barriers to full gender equality persist in South Africa. Afrobarometer, 324(324), 1-13. https://media.africaportal.org/documents/ab_r7 _dispatchno324_despite_laws_gender_disparities_persist_in_south_africa.pdf

Espi, G., Francis, D., \& Valodia, I. (2019). Gender inequality in the South African labour market: Insights from the Employment Equity Act data. Agenda, 33(4), 44-61. https://doi.org/10.1080/10130950.2019.1674675

Fourie, F. C.v.N. (2011). The South African unemployment debate: three worlds, three discourses? A Southern Africa Labour and Development Research Unit Working Paper Number 63. Cape Town: SALDRU, University of Cape Town, ISBN: 978-1-920517-04-5, http://opensaldru.uct.ac.za/bitstream/handle/11090/80/2011_63.pdf?sequence=

Frankiewicz, B. (2020). 5 Ways We Lack Gender Balance in the Workplace. World Economic_Forum.https://www.weforum.org/agenda/2020/01/5-ways-companies-canprogress-more-women-into-leadership-roles/

Geisler, G. (2009). South Africa - The National Gender Machinery, Gender Mainstreaming and the Fight against Gender Based Violence, African development Department, African development Fund, Human Development Department, https://www.afdb.org/fileadmin/uploads/afdb/Documents/Project-and-Operations/South\%20Africa\%20\%20The\%20National\%20Gender\%20Machinery\%20Gender\%20Mainstreaming.pdf

Government, S.A. (2021). President Cyril Ramaphosa : Cabinet announcement. 1-10.

Hills, J. (2015). Addressing gender quotas in South Africa: women empowerment and gender equality legislation. Deakin Law Review, 20(1), https://ojs.deakin.edu.au/index.php/dlr/article/view/498/500

Huang, G. (2017). Seeking Women: 70 + Companies That Have Set Gender Diversity Targets. Forbes, 2017-2020.

Kehler, J. (2001). Women and Poverty: The South African Experience. Journal of International Women's Studies, 3(1), 41-53. http://vc.bridgew.edu/jiws/vol3/issl/3

Kelly-Gadol, J. (1976). The Social Relation of the Sexes: Methodological Implications of Women's History. Signs: Journal of Women in Culture and Society, 1(4), 809-823. https://doi.org/10.1086/493302

Khuzwayo, Z. (2016). Separate space: An approach to addressing gender inequality in the workplace. Journal of International Women's Studies, 17(4), 91-101.

Kok, A. (2008). The promotion of equality and prevention of unfair discrimination act 4 of 2000: Proposals for legislative reform. South African Journal on Human Rights, 24(3), 445-471. https://doi.org/10.1080/19962126.2008.11864965

Kornergay Ellen. (1999). South Africa's National Policy Framework for Women's Empowerment and Gender Equality, Prepared by: The Office on the Status of Women. Statistics, 1-64, Gender Policy - ILO

Madala, T.H. (1999). Affirmative Action - A South African Perspective. 52(4), 1539-1548.

Meintjes, S. (2005). Gender equality by design: The case of south africa's commission on gender equality. Politikon, 32(2), 259-275. https://doi.org/10.1080/02589340500353631

Naidoo, V., \& Kongolo, M. (2004). Has affirmative action reached south African women?. Journal of International Women's Studies, 6(1), 124-136.

National Minimum Wage Panel. (2016). Recommendations on Policy and Implementation. National Minimum Wage Panel Report To the Deputy President. 1-129. 
http://www.treasury.gov.za/publications/other/NMW Report Draft CoP FINAL.PDF

O'Brien, S. (2019). How to Recruit More Women to Your Company. Harvard Business Review, 2-6. https://hbr.org/2019/11/how-to-recruit-more-women-to-your-company

Ortiz-Ospina, E., \& Roser, M. (2018). Economic inequality by gender. OurWorldInData.Org, March, 1-38. https://ourworldindata.org/economic-inequality-bygender

Parashar, S. (2014). Marginalized by race and place: A multilevel analysis of occupational sex segregation in post-apartheid South Africa. International Journal of Sociology and Social Policy, 34, 747-770. https://doi.org/10.1108/IJSSP-01-2014-0003

Provisions, F., President, T., Executive, N., Government, L., Institutions, S., \& Constitutional, S. (1909). The Constitution of South Africa. American Journal of International Law, 3(3), 691-694. https://doi.org/10.2307/2186692

Republic of South Africa (RSA). (1996). Constitution of the Republic of South Africa, Act No 108 of 1996. Government Printers, Pretoria.

Rospabé, S. (2001). An empirical evaluation of gender discrimination in employment, occupation attainment and wage in South Africa in the late 1990's. 1-40.

RSA. (1996). Employment Equity Act, 1998. Act No 55 of 1998. Government Printers, Pretoria. https://www.labourguide.co.za/download-top/135-eepdf/file

RSA. (1996). Commission on Gender Equality Act, no 39 of 1996. Government Printers. Pretoria.https://www.parliament.gov.za/storage/app/media/ProjectsAndEvents/womens_mont h_2015/docs/Act39of1996.pdf

RSA. (2000). Promotion Promotion of Equality and Prevention of Unfair Discrimination Act, No 4 of 2000. Government Printers, Pretoria.

https://www.justice.gov.za/legislation/acts/2000-004.pdf

RSA. (2000). South Africa's National Policy Framework for Women's Empowerment and Gender Equality. Office of the Status of Women. Office of the Presidency. South Africa. https://www.ilo.org/dyn/natlex/natlex4.detail?p_isn=94056\&p_lang=en

RSA. (2013). Women Empowerment and Gender Equality Bill, B 50-2013, No 37005. Government_Printers,Pretoria.https://www.gov.za/sites/default/files/gcis_document/201409/b 50-2013womenempowermentgenderequality06nov2013.pdf

Seidman, G. W. (1993). "No Freedom without the Women": Mobilization and Gender in South Africa, 1970-1992. Signs: Journal of Women in Culture and Society, 18(2), 291-320. https://doi.org/10.1086/494794

Sinden, E. (2017). Exploring the Gap Between Male and Female Employment in the South African Workforce. Mediterranean Journal of Social Sciences, 8(6), 37-51. https://doi.org/10.1515/mjss-2017-0040

Standing, G., Sender., \& Weeks, J. (1996). Restructuring the Labour Market: South Africa challenge. International Labour Organization, Geneva

UN. (2020). Women's Rights in Review 25 Years after Beijing. Avaialble at: https://www.un-ilibrary.org/content/books/9789210049368/read

Wu, R., \& Cheng, X. (2018). Gender equality in the workplace: The effect of gender equality on productivity growth among the Chilean manufacturers. The Journal of Developing Areas, 50(1), 257-274, doi:10.1353/jda.2016.0001

20th Commission for Employment Equity Annual Report 2019/20. Department of labor. http://www.labour.gov.za/DocumentCenter/Reports/Annual\%20Reports/Employment\%20Eq uity/2019\%20-2020/20thCEE_Report.pdf 